\title{
Recent advances in understanding antitumor immunity
}

\section{[version 1; peer review: 3 approved]}

\section{Rodrigo Ramella Munhoz ${ }^{1}$, Michael Andrew Postow 2,3}

\author{
${ }^{1}$ Melanoma/Sarcoma Group, Oncology Center, Hospital Sírio Libanês, São Paulo, Brazil \\ ${ }^{2}$ Melanoma and Immunotherapeutics Service, Memorial Sloan Kettering Cancer Center, New York, NY, USA \\ ${ }^{3}$ Weill Cornell Medical College, New York, NY, USA
}

V1 First published: 20 Oct 2016, 5(F1000 Faculty Rev):2545

https://doi.org/10.12688/f1000research.9356.1

Latest published: 20 Oct 2016, 5(F1000 Faculty Rev):2545

https://doi.org/10.12688/f1000research.9356.1

\begin{abstract}
The term "antitumor immunity" refers to innate and adaptive immune responses which lead to tumor control. Turning the immune system into a destructive force against tumors has been achieved in a broad range of human cancers with the use of non-specific

immunotherapies, vaccines, adoptive-cell therapy, and, more recently with significant success, through blockade of immune checkpoints. Nevertheless, the efficacy of these approaches is not universal, and tools to identify long-term responders and primarily refractory patients are warranted. In this article, we review recent advances in understanding the complex mechanisms of antitumor immunity and how these developments can be used to address open questions in a setting of growing clinical indications for the use of immunotherapy.
\end{abstract}

Keywords

antitumour immunity, immune response, tumour immunotherapies

\section{Open Peer Review \\ Approval Status \\ 12 \\ 3 \\ version 1 \\ 20 Oct 2016 \\ Faculty Reviews are review articles written by the prestigious Members of Faculty Opinions. The articles are commissioned and peer reviewed before publication to ensure that the final, published version is comprehensive and accessible. The reviewers who approved the final version are listed with their names and affiliations.}

1. Karine Breckpot, Vrije Universiteit Brussel, Brussels, Belgium

2. Timothy M Illidge, The University of Manchester, Manchester, UK

3. Daniel Speiser, Ludwig Center for Cancer

Research, University of Lausanne, Epalinges,

Switzerland

Any comments on the article can be found at the end of the article. 
Corresponding author: Rodrigo Ramella Munhoz (rodrigo.rmunhoz@hsl.org.br)

Competing interests: Rodrigo R. Munhoz has received honoraria from AstraZeneca, BMS, MSD, and Roche; has had an advisory role for Roche and MSD; and has received travel expenses from AstraZeneca, BMS, MSD, and Roche. Michael A. Postow has received honoraria from BMS and Merck; has had an advisory role for BMS and Amgen; and has received research funding from BMS.

Grant information: Michael A. Postow has received research funding from BMS.

Copyright: ( 2016 Munhoz RR and Postow MA. This is an open access article distributed under the terms of the Creative Commons Attribution License, which permits unrestricted use, distribution, and reproduction in any medium, provided the original work is properly cited.

How to cite this article: Munhoz RR and Postow MA. Recent advances in understanding antitumor immunity [version 1; peer review: 3 approved] F1000Research 2016, 5(F1000 Faculty Rev):2545 https://doi.org/10.12688/f1000research.9356.1

First published: 20 Oct 2016, 5(F1000 Faculty Rev):2545 https://doi.org/10.12688/f1000research.9356.1 


\section{Introduction}

Using the immune system to fight cancer has been confirmed as one of the major breakthroughs in oncology, yielding the possibility of long-term clinical benefit and prolonged survival. Despite the recent advances with immune checkpoint-directed approaches, the concept of "immunotherapy" dates back to the $19^{\text {th }}$ and early $20^{\text {th }}$ century with Wilhelm Busch, William B. Coley, and Paul Ehrlich and comprises distinct strategies, including vaccines, nonspecific cytokines, and adoptive cell therapies ${ }^{1}$. The introduction of monoclonal antibodies targeting co-receptors of immune activation resulted in unprecedented benefits in the management of distinct malignancies, with exceptional results in melanoma, renal cell carcinoma, Merkel cell carcinoma, lung cancer, urothelial carcinoma, and other neoplasms ${ }^{2-7}$.

Nevertheless, despite the certainties already available that are redefining the landscape of cancer treatment, several questions emerged to daunt clinicians and scientists: how do we select the best candidates for therapy? What factors are involved in primary and acquired resistance? What are the best biomarkers to guide treatment decisions and rationalize costs? How do we pick the best combinations to optimize outcomes?

Elucidating the mechanisms regulating the interactions between the immune system and cancer cells is critical in order to provide tools to address the growing number of open questions, overcome resistance, and broaden the benefits of immunotherapy to more patients.

\section{The tumor-host immune system interaction and role of co-receptors}

The immune system can be activated by tumor antigens and, once primed, can elicit an antitumor response which in some cases can result in tumor destruction. Unfortunately, the successful development of antitumor immunity is often hampered by a plethora of factors that can directly determine the adequacy of the immune response. The singular event illustrated by a cytotoxic lymphocyte interacting with a tumor cell holds a background of a series of complex mechanisms, encompassed under the concepts of "immunosurveillance" and "immunoediting",9. Critical aspects in the tumor-immune system interface include the processing and presentation of released antigens by antigen-presenting cells (APCs), interaction with $\mathrm{T}$ lymphocytes, subsequent immune/T-cell activation, trafficking of antigen-specific effector cells, and, ultimately, the engagement of the target tumor cell by the activated effector T cell ${ }^{10,11}$. Nevertheless, although often successful in preventing tumor outgrowth, this "cancer-immunity cycle" can be disrupted by artifices involved in immune escape and development of tolerance, culminating with the evasion and proliferation of malignant cells ${ }^{9-11}$.

T-cell activation relies on the interaction of the T-cell receptor with antigens presented as peptides through the major histocompatibility complex (MHC) by the APC. Tumor antigens are classified as tumor-specific antigens (TSAs), derived from cancergermline genes, point mutations or oncogenic viruses and unique to tumor cells, or tumor-associated antigens (TAAs), which include differentiation antigens (tyrosinase, gp100, Melan-A/MART-1, carcinoembryonic antigen, prostate-specific antigen, prostatic acidic phosphatase, etc.) and peptides associated with genes overexpressed in tumors (survivin, erbB-2 or CD340, RAGE-1, PRAME, and WT1) $)^{12,13}$. HLA downregulation has been shown to result in decreased antigenicity and therefore acts as a mechanism of immune evasion ${ }^{14}$.

While the recognition of peptide-MHC by the TCR plays a central role in the process of T-cell-mediated immunity, additional cell-surface co-receptors are mandatory for the modulation of the immune response, either positively or negatively ${ }^{15,16}$. Two of these inhibitory co-receptors, called immune checkpoints, are involved in adaptive immune resistance and T-cell tolerance and have been exploited clinically with the development of checkpoint-blocking monoclonal antibodies. The two receptors include the cytotoxic T-lymphocyte-associated protein 4 (CTLA-4, also known as CD152) and the programmed cell death receptor 1 (PD-1 or CD279) and its ligand (PD-L1, also named CD274 or B7-H1) ${ }^{16}$. Additional inhibitory receptors include B- and T-cell attenuator (BTLA or CD272), lymphocyte-activation protein 3 (LAG-3 or CD223), T-cell immunoglobulin and mucin protein-3 (TIM-3, also termed hepatitis A virus cellular receptor 2 - HAVCR2 - or CD366), and V-domain immunoglobulin-containing suppressor of T-cell activation (VISTA, B7H5, or programmed death 1 homolog - PD-1H) ${ }^{16-18}$. Also potential targets for therapeutic manipulation, co-stimulatory receptors associated with positive modulation of the immune synapse include CD27, CD28, CD137, inducible T-cell costimulator (ICOS or CD278), herpesvirus entry mediator (HVEM, also known as tumor necrosis factor receptor superfamily member 14 - TNFRSF14), and glucocorticoid-induced TNFR-related protein (GITR or tumor necrosis factor receptor superfamily member 18 - TNFRSF18). It is important to highlight, however, that the list of co-receptors and ligands encompasses both co-inhibitory and co-stimulatory molecules other than those aforementioned, some of which are not fully characterized.

The mobilization of these components of the adaptive immune system involved in antitumor immunity, including CD4+ helper $\mathrm{T}$ cells and CD8+ effector $\mathrm{T}$ cells, are largely influenced by a milieu of variables that involve intrinsic tumor characteristics, microenvironment factors, and genetic/epigenetic determinants ${ }^{19}$.

\section{Tumor antigenic potential}

Antigens are paramount in immune responses mediated by $\mathrm{T}$ cells; indeed, histologies that served as proofs of concept for the development of immunotherapy, including melanoma and renal cell carcinoma, have long been characterized as potentially "immunogenic" or "antigenic" 19,20 . Antigen-directed T-cell activation can result from the presentation of tumor self-peptides or peptides/neoantigens that emerge from aberrant gene products. As a consequence, the tumor genomic landscape or mutational load would represent a logical surrogate of the immunogenicity or "foreignness" of distinct malignancies through the generation of neoepitopes ${ }^{21,22}$.

Indeed, prolonged patient survival has been associated with an increased number of somatic missense mutations and mutational epitopes $^{23}$. More importantly, a correlation between the mutational burden and clinical benefit has been seen in the setting of immune-checkpoint blockade ${ }^{24-26}$. Snyder et al. was able to demonstrate an association between outcomes following anti-CTLA-4 
therapy in melanoma and a high mutational load. Of note, although a high mutational load increased the probability of an "immunogenic" neoepitope signature, these variables were not completely overlapping. An even more intriguing finding was that candidate neoepitopes were homologous to distinct viral and bacterial antigens $^{24}$. Some similar findings were reported by Van Allen and colleagues based on an expanded cohort of 110 patients with metastatic melanoma; using transcriptome data, a correlation among the expression of cytolytic genes, neoantigen load, and clinical benefit to CTLA-4 was also demonstrated ${ }^{25}$.

The mutational landscape was also found to be a determinant of clinical benefit from PD-1 blockade in patients with non-small-cell lung cancer (NSCLC); moreover, responses were more frequent in the setting of environmental exposure to tobacco, determined using a molecular signature of smoking that also correlated with a higher number of non-synonymous mutations ${ }^{26}$. Serving as a strong proof of principle, blockade of PD-1 resulted in clinically meaningful activity in patients with mismatch repair (MMR) deficiencyassociated tumors ${ }^{27}$, characterized by a large number of somatic mutations and rich in expression of immune inhibitors (PD-1, PD-L1, LAG-3, and indoleamine 2,3 dioxygenase [IDO] $)^{28}$. Nevertheless, the correlation among mutational burden, the generation of neoantigens/neoepitopes, and the activation of antigen-specific $\mathrm{T}$ cells is not linear and neoepitopes may not be universally presented by the $\mathrm{MHC}^{29,30}$. Some studies have also suggested that mutational load may be prognostic but not necessarily predictive for responses to PD-1 therapy in melanoma ${ }^{31}$. In addition, while clonal neoantigens may drive CD8+ T-cell responses and predict responses to PD-1 and CTLA-4 blockade, the clinical impact of subclonal mutations is largely debatable and arguably marginal, despite being associated with increased mutational load ${ }^{32}$.

Albeit intuitive, the tumor antigenic potential is not driven solely by the total mutational load, as other antigens can also be immunogenic. Additional insults to the DNA other than the number of mutations can result in potentially neoantigenic epitopes, and oncogenic viruses could be determinant in the cancer-host immune system interaction and antigenicity. In Merkel cell carcinoma, the presence of Merkel cell polyomavirus (MCPyV) DNA and tumor-infiltrating lymphocytes and the expression of PD-L1 support the existence of intrinsic antitumor immunity ${ }^{33}$. Indeed, PD-1 blockade resulted in meaningful clinical activity in Merkel cell carcinoma patients, particularly in those associated with $\mathrm{MCPyV}$, despite a lower mutational burden in this subgroup ${ }^{4}$.

While most studies have investigated the mutational profile of tumors as a surrogate for "tumor antigenicity" as a potential pretreatment biomarker of responsiveness to checkpoint blockade, a recent study specifically examined the mutational profile of resistant lesions that arose in patients with melanoma who previously benefitted from PD-1 therapy. Although the number of patients examined in this series was small $(n=4)$, some secondary resistant lesions had mutations in the interferon (IFN) (JAK mutations) and antigen-presentation (beta-2-microglobulin) pathways, suggesting possible mechanisms of immune escape from PD- $1^{34}$. Additional study in larger patient cohorts would be of value.

\section{Tumor microenvironment factors and pre-existing host immune conditions}

Despite the central role of intrinsic antigenicity, tumor immunogenicity is directly influenced by a plethora of immunomodulatory factors co-existing in the tumor microenvironment that derive from both tumor cells and host cells. Also intuitive, the concept that "inflamed" or "hot" tumors may derive greater benefit from immunotherapy is supported by mounting evidence.

The characterization of the T-cell infiltrate has been associated with both innate antitumor immunity and benefit from immunecheckpoint blockade. The density of antigen-specific effector $\mathrm{T}$ cells within the tumor microenvironment and invasive margin is a predictor of survival in patients with colorectal cancer, and the concept that pre-treatment adaptive immune responses and immune infiltrates directly influence the natural course of different malignancies is consistent across different studies ${ }^{35,36}$. Pre-existing CD8+ T cells located at the invasive tumor margin are aligned with expression of PD-1 and PD-L1 ${ }^{37}$. Additionally, increased CD8+ T-cell infiltrates within the tumor microenvironment directly correlated with benefit from PD-1 blockade ${ }^{37,38}$. An association between absolute lymphocyte count in the peripheral blood of patients who received anti-CTLA-4 therapy and clinical benefit has also been shown as an increase in lymphocyte count during treatment or at baseline ${ }^{39,40}$. Also, anti-CTLA-4 treatment was demonstrated to result in newly detected CD8+ T-cell responses measured in post-treatment samples, suggesting that CTLA-4 blockade has a direct role in increasing T-cell priming ${ }^{41}$.

Increased levels of IFN- $\gamma$ and expression of ICOS on peripheral lymphocytes and tumor-infiltrating lymphocytes has been demonstrated in the setting of CTLA-4 blockade ${ }^{42}$, providing the rationale for additional combined approaches. CD4+ T cells with increased ICOS expression also correlated with an increase in effector/ regulatory $\mathrm{T}$-cell ratio $^{43}$.

Factors involved in the modulation of the tumor and immune microenvironment are also crucial in understanding the tumor-host immune system interaction. In metastatic melanoma samples, cell lines, and xenografts, T-cell and macrophage recruitment occurred more frequently in association with the expression of a subset of chemokines (CCL2, CCL3, CCL4, CCL5, CXCL9, and CXCL10) associated with an "inflamed" phenotype ${ }^{44,45}$. Indeed, CXCL9 and CXCL10, ligands of CXCR3, were incorporated in a gene signature associated with responses to anti-PD-1 treatment and indicative of an inflamed microenvironment ${ }^{46}$. Similarly, the presence of tumor-reactive cells correlated with endogenous accumulation of type I IFNs (IFN- $\alpha$, IFN- $\beta$, IFN- $\varepsilon$, IFN- $\kappa$, and IFN- $\omega)^{47}$. In a topic of significant clinical relevance, the regulation of genes associated with IFN signaling was achieved with the use of azacitidine, a DNA methyltransferase inhibitor, through the epigenetic regulation of gene promoters normally silenced ${ }^{48}$.

Nevertheless, T-cell infiltration is also accompanied by the induction of tolerance mechanisms largely involved in the abrogation of an effective antitumor immune response. These so-called inhibitory pathways involve the expression of IDO and PD-L1, induced 
by IFN- $\gamma$, and recruitment of FoxP3+CD4+ (regulatory T) cells through CCL22 in the setting of CD8+ T-cell activation ${ }^{49}$.

In melanoma lesions and other malignancies, the expression of PD-L1 has been associated with the presence of tumor-infiltrating lymphocytes, IFN- $\gamma$ expression, and improved survival in some studies $^{33,50-52}$. While straightforward, using the expression of PD-L1 as a biomarker poses a series of caveats and uncertainties. PD-L1 is expressed in macrophages and, in the setting of immune activation, in B, T, myeloid, and dendritic cells (DCs) as well as in nonhematopoietic and endothelial cells ${ }^{53}$. Indeed, the early clinical development of anti-PD-1 agents already suggested that tumors rich in PD-L1 expression were more likely to respond to therapy ${ }^{54}$, although this correlation is imperfect. It is important to emphasize that PD-L1 expression occurs along a spectrum of positivity and is dynamic and heterogeneous between and within tumors. The expression of PD-L1 can occur constitutively, or it can be induced upon T-cell activation ${ }^{49,50,55}$. In addition to analytical technical issues detecting PD-L1, pre-testing factors (distribution, cell population by which PD-L1 is expressed, etc.) and intrapatient, intertumor heterogeneity pose significant limitations to the interpretation of PD-L1 expression ${ }^{56}$.

Similarly, the expansion of regulatory $\mathrm{T}$ cells and myeloidderived suppressor cells (MDSCs) also represents a mechanism of immune escape, suggesting that additional immunosuppressive factors may need to be targeted to increase antitumor immunity. In murine models, inhibition of MDSC trafficking by CXCR2 deficiency or CXCR2 signaling blockade increased the efficacy of anti-PD-1 therapy ${ }^{57}$. It has been demonstrated in pre-clinical models that inhibition of regulatory $\mathrm{T}$ cells may be necessary for anti-CTLA-4-induced antitumor activity ${ }^{58}$. Moreover, the efficacy of anti-CTLA-4 therapy has been associated with regulatory T-cell depletion in the presence of $\mathrm{Fc} \gamma$ receptor-expressing macrophages, suggesting that the mechanisms involved in immune activation may be more diverse than anticipated ${ }^{59}$.

In addition to the aforementioned factors related to pre-existing immune conditions and regulation within the tumor microenvironment, antitumor immunity can also be affected by a very particular variable: the host microbiota. Across different studies, intestinal commensal bacteria have been shown to influence T-cell differentiation, APC activation, and antitumor immunity modulation ${ }^{60,61}$. In a demonstration of this principle, fecal material transfer between two murine populations resulted in infiltration of tumor-specific CD8+ $\mathrm{T}$ cells and delayed tumor growth, an effect attributed to the colonization by Bifidobacterium species. Of note, in addition to innate antitumor immunity, oral administration of Bifidobacterium also potentiated the antitumor effect of PD-L1 blockade ${ }^{62}$.

\section{Genetic, epigenetic, and signaling modulators of the immune response}

If it is now well established that immune responses can be influenced by genomic correlates, including the burden of non-synonymous mutations, emerging evidence suggests that specific genetic variables are also involved in direct modulation of antitumor immunity.
Distinct somatic mutations have been shown to be related to intratumoral immunity. As an example, restoration of p53 signaling has been associated with the activation of tumor-directed innate immune cells, natural killer cell recruitment, and chemokine production $^{63,64}$. Another study showed a low mutational burden was associated with PD-L1 negativity and worse survival ${ }^{65}$. In melanoma cell lines, disruptive mutations of JAK1 or JAK2 (downstream elements of IFN signaling) have been shown to abrogate PD-L1 expression upon exposure to IFN- $\gamma$, suggesting a mechanism for innate resistance to PD-1 blockade ${ }^{66}$. In NSCLC samples, expression of PD-L1 and PD-L1 gene amplification correlated with simultaneous amplification of JAK2, whereas JAK2 inhibition resulted in reduced expression of PD-L1 protein ${ }^{67}$. Conversely, PI3K-AKT pathway activation resulting from PTEN loss has been shown to correlate with immunoresistance mediated by PD-L1 and PD-L2 expression in preclinical models as well as in a clinical series ${ }^{55,68}$. An immune translation of somatic events has also been reported for aberrations involving STAT3/ALK signaling and EGFR mutations ${ }^{69,70}$. In melanoma metastases, mutations involved in activation of the WNT/ $\beta$-catenin pathway were associated with a non-T-cell inflamed phenotype and T-cell exclusion from the tumor microenvironment ${ }^{71}$.

Besides T-cell activation, DC mobilization can be modulated by distinct genetic pathways involved in innate immune sensing of immunogenic tumors. As an example, knockout mice deficient for the transcription factor Batf3, involved in DC recruitment and activation through type I IFNs, show impaired CD8+ T-cell activation $^{72}$. As a corollary, tumor-infiltrating DCs can be artificially manipulated in order to induce antitumor immunity, as demonstrated in preclinical models in which intratumoral delivery of mRNA involved in the activation of cross-presenting DCs resulted in T-cell responses ${ }^{73}$. Similarly, defective spontaneous T-cell priming has been demonstrated in models lacking the cytosolic receptor stimulator of IFN genes complex (STING), which is involved in type I IFN and proinflammatory cytokine responses. In line with these observations, vaccines with STING ligands were able to induce DCs, PD-L1 upregulation, and antigen-specific T-cell activation in preclinical models ${ }^{74}$.

\section{Conclusions}

It is well known that the characterization of basic mechanisms underlying antitumor immunity has paved the way for the development of therapeutic strategies to manipulate antitumor immunity for favorable patient benefit. The interplay among different factors driving the tumor-host immune response is not fully characterized, and the complexity of these factors has been summarized by Blank and colleagues as the "cancer immunogram" 75 . The understanding of these multiple regulatory pathways involved in antitumor immunity is crucial not only for patient selection and therapeutic decisions but also for improving outcomes through combined approaches. In addition, despite the significant clinical results and survival improvements seen in patients with some cancers, primary and acquired/secondary resistance to immunotherapy remain challenges. Future research will be critical in addressing the large body of questions which remains to be answered. 
Competing interests

Rodrigo R. Munhoz has received honoraria from AstraZeneca, BMS, MSD, and Roche; has had an advisory role for Roche and MSD; and has received travel expenses from AstraZeneca, BMS, MSD, and Roche. Michael A. Postow has received honoraria from
BMS and Merck; has had an advisory role for BMS and Amgen; and has received research funding from BMS.

Grant information

Michael A. Postow has received research funding from BMS.
1. Curiel TJ: Historical perspectives and current trends in cancer immunotherapy. In: Cancer Immunotherapy: Paradigms, Practice and Promise. Curiel TJ (Ed.). Springer; New York, NY USA, 2012.

Publisher Full Text

2. F Hodi FS, O'Day SJ, McDermott DF, et al.: Improved survival with ipilimumab in patients with metastatic melanoma. N Engl J Med. 2010; 363(8): 711-23. PubMed Abstract | Publisher Full Text | Free Full Text | F1000 Recommendation

3. $\quad F$ Borghaei H, Paz-Ares L, Horn L, et al:: Nivolumab versus Docetaxel in Advanced Nonsquamous Non-Small-Cell Lung Cancer. N Engl J Med. 2015; 373(17): 1627-39.

PubMed Abstract | Publisher Full Text | F1000 Recommendation

4. $\quad F$ Nghiem PT, Bhatia S, Lipson EJ, et al:: PD-1 Blockade with Pembrolizumab in Advanced Merkel-Cell Carcinoma. N Engl J Med. 2016; 374(26): 2542-52. PubMed Abstract | Publisher Full Text | Free Full Text | F1000 Recommendation

5. $\quad F$ Rosenberg JE, Hoffman-Censits J, Powles T, et al:: Atezolizumab in patients with locally advanced and metastatic urothelial carcinoma who have progressed following treatment with platinum-based chemotherapy: a singlearm, multicentre, phase 2 trial. Lancet. 2016; 387(10031): 1909-20. PubMed Abstract | Publisher Full Text | F1000 Recommendation

6. $\mathrm{F}$ Robert $\mathrm{C}$, Long GV, Brady B, et al:: Nivolumab in previously untreated melanoma without BRAF mutation. N Engl J Med. 2015; 372(4): 320-30. PubMed Abstract | Publisher Full Text | F1000 Recommendation

7. F Robert C, Schachter J, Long GV, et al:: Pembrolizumab versus Ipilimumab in Advanced Melanoma. N Engl J Med. 2015; 372(6): 2521-32. PubMed Abstract | Publisher Full Text | F1000 Recommendation

8. Burnet FM: The concept of immunological surveillance. Prog Exp Tumor Res 1970; 13: 1-27.

PubMed Abstract | Publisher Full Text

9. Dunn GP, Bruce AT, Ikeda $\mathrm{H}$, et al.: Cancer immunoediting: from immunosurveillance to tumor escape. Nat Immunol. 2002; 3(11): 991-8. PubMed Abstract | Publisher Full Text

10. F Hanahan D, Weinberg RA: Hallmarks of cancer: the next generation. Cell. 2011; 144(5): 646-74.

PubMed Abstract | Publisher Full Text | F1000 Recommendation

11. Chen DS, Mellman I: Oncology meets immunology: the cancer-immunity cycle. Immunity. 2013; 39(1): 1-10.

PubMed Abstract | Publisher Full Text

12. van der Bruggen $P$, Traversari $C$, Chomez $P$, et al.: A gene encoding an antigen recognized by cytolytic T lymphocytes on a human melanoma. Science. 1991; 254(5038): 1643-7.

PubMed Abstract | Publisher Full Text

13. Vigneron N: Human Tumor Antigens and Cancer Immunotherapy. Biomed Res Int. 2015; 2015: 948501

PubMed Abstract | Publisher Full Text | Free Full Text

14. Shukla SA, Rooney MS, Rajasagi M, et al.: Comprehensive analysis of cancerassociated somatic mutations in class I HLA genes. Nat Biotechnol. 2015; 33(11): 1152-8.

PubMed Abstract | Publisher Full Text | Free Full Text

15. Greenwald RJ, Freeman GJ, Sharpe AH: The B7 family revisited. Annu Rev Immunol. 2005; 23: 515-48.

PubMed Abstract | Publisher Full Text

16. Pardoll DM: The blockade of immune checkpoints in cancer immunotherapy Nat Rev Cancer. 2012; 12(4): 252-64.

PubMed Abstract | Publisher Full Text | Free Full Text

17. Lines JL, Sempere LF, Broughton T, et al:: VISTA is a novel broad-spectrum negative checkpoint regulator for cancer immunotherapy. Cancer Immunol Res. 2014; 2(6): 510-7.

PubMed Abstract | Publisher Full Text | Free Full Text

18. Mellman I, Coukos G, Dranoff G: Cancer immunotherapy comes of age. Nature. 2011; 480(7378): 480-9.

PubMed Abstract | Publisher Full Text | Free Full Text

19. Blankenstein T, Coulie PG, Gilboa E, et al:: The determinants of tumour immunogenicity. Nat Rev Cancer. 2012; 12(4): 307-13. PubMed Abstract | Publisher Full Text | Free Full Text
20. Alexandrov LB, Nik-Zainal S, Wedge DC, et al:: Signatures of mutational processes in human cancer. Nature. 2013; 500(7463): 415-21. PubMed Abstract | Publisher Full Text | Free Full Text

21. F Matsushita H, Vesely MD, Koboldt DC, et al:: Cancer exome analysis reveals a T-cell-dependent mechanism of cancer immunoediting. Nature. 2012; 482(7385): 400-4

PubMed Abstract | Publisher Full Text | Free Full Text | F1000 Recommendation

22. van Rooij N, van Buuren MM, Philips D, et al.: Tumor exome analysis reveals neoantigen-specific T-cell reactivity in an ipilimumab-responsive melanoma. J Clin Oncol. 2013; 31(32): e439-42.

PubMed Abstract | Publisher Full Text | Free Full Text

23. F Brown SD, Warren RL, Gibb EA, et al:: Neo-antigens predicted by tumor genome meta-analysis correlate with increased patient survival. Genome Res. 2014; 24(5): 743-50.

PubMed Abstract | Publisher Full Text | Free Full Text | F1000 Recommendation

24. F Snyder A, Makarov V, Merghoub T, et al.: Genetic basis for clinical response to CTLA-4 blockade in melanoma. N Engl J Med. 2014; 371(23): 2189-99. PubMed Abstract | Publisher Full Text | Free Full Text | F1000 Recommendation

25. $F$ van Allen EM, Miao D, Schilling B, et al.: Genomic correlates of response to CTLA-4 blockade in metastatic melanoma. Science. 2015; 350(6257): 207-11. PubMed Abstract | Publisher Full Text | Free Full Text | F1000 Recommendation

26. F Rizvi NA, Hellmann MD, Snyder A, et al:: Cancer immunology. Mutational landscape determines sensitivity to PD-1 blockade in non-small cell lung cancer. Science. 2015; 348(6230): 124-8.

PubMed Abstract | Publisher Full Text | Free Full Text | F1000 Recommendation

27. F Le DT, Uram JN, Wang H, et al.: PD-1 Blockade in Tumors with MismatchRepair Deficiency. N Engl J Med. 2015; 372(26): 2509-20.

PubMed Abstract | Publisher Full Text | Free Full Text | F1000 Recommendation

28. Llosa NJ, Cruise M, Tam A, et al:: The vigorous immune microenvironment of microsatellite instable colon cancer is balanced by multiple counter-inhibitory checkpoints. Cancer Discov. 2015; 5(1): 43-51.

PubMed Abstract | Publisher Full Text | Free Full Text

29. Yadav M, Jhunjhunwala S, Phung QT, et al:: Predicting immunogenic tumour mutations by combining mass spectrometry and exome sequencing. Nature. 2014; 515(7528): 572-6.

PubMed Abstract | Publisher Full Text

30. Tran E, Ahmadzadeh M, Lu YC, et al:: Immunogenicity of somatic mutations in human gastrointestinal cancers. Science. 2015; 350(6266): 1387-90. PubMed Abstract | Publisher Full Text

31. F McGranahan N, Furness AJ, Rosenthal R, et al:: Clonal neoantigens elicit T cell immunoreactivity and sensitivity to immune checkpoint blockade. Science. 2016; 351(6280): 1463-9.

PubMed Abstract | Publisher Full Text | Free Full Text | F1000 Recommendation

32. $\mathrm{F}$ Hugo W, Zaretsky JM, Sun L, et al:: Genomic and Transcriptomic Features of Response to Anti-PD-1 Therapy in Metastatic Melanoma. Cell. 2016; 165(1): 35-44.

PubMed Abstract | Publisher Full Text | Free Full Text | F1000 Recommendation

33. Lipson EJ, Vincent JG, Loyo M, et al: PD-L1 expression in the Merkel cell carcinoma microenvironment: association with inflammation, Merkel cell polyomavirus and overall survival. Cancer Immunol Res. 2013; 1(1): 54-63. PubMed Abstract | Publisher Full Text | Free Full Text

34. F Zaretsky JM, Garcia-Diaz A, Shin DS, et al:: Mutations Associated with Acquired Resistance to PD-1 Blockade in Melanoma. N Engl J Med. 2016 375(9): 819-29.

PubMed Abstract | Publisher Full Text | Free Full Text | F1000 Recommendation

35. F Galon J, Costes A, Sanchez-Cabo F, et al.: Type, density, and location of immune cells within human colorectal tumors predict clinical outcome. Science. 2006; 313(5795): 1960-4.

PubMed Abstract | Publisher Full Text | F1000 Recommendation

36. Fridman $\mathrm{WH}$, Pages $\mathrm{F}$, Sautes-Fridman $\mathrm{C}$, et al:: The immune contexture in human tumours: impact on clinical outcome. Nat Rev Cancer. 2012; 12(4): 298-306. PubMed Abstract | Publisher Full Text 
37. F Tumeh PC, Harview CL, Yearley JH, et al:: PD-1 blockade induces responses by inhibiting adaptive immune resistance. Nature. 2014; 515(7528): 568-71. PubMed Abstract | Publisher Full Text | Free Full Text | F1000 Recommendation

38. Brahmer JR, Drake CG, Wollner I, et al:: Phase I study of single-agent antiprogrammed death-1 (MDX-1106) in refractory solid tumors: safety, clinical activity, pharmacodynamics, and immunologic correlates. J Clin Oncol. 2010; 28(19): 3167-75.

PubMed Abstract | Publisher Full Text | Free Full Text

39. Postow MA, Chasalow SD, Yuan J, et al:: Evaluation of the absolute lymphocyte count as a biomarker for melanoma patients treated with the commercially available dose of ipilimumab (3mg/kg). J Clin Oncol. 2012; 30(Suppl): abstract 8575. Reference Source

40. Ku GY, Yuan J, Page DB, et al:: Single-institution experience with ipilimumab in advanced melanoma patients in the compassionate use setting: lymphocyte count after 2 doses correlates with survival. Cancer. 2010; 116(7): 1767-75. PubMed Abstract | Publisher Full Text | Free Full Text

41. F Kvistborg P, Philips D, Kelderman S, et al:: Anti-CTLA-4 therapy broadens the melanoma-reactive CD8 ${ }^{+}$T cell response. Sci Transl Med. 2014; 6(254): 254ra128. PubMed Abstract | Publisher Full Text | F1000 Recommendation

42. Chen $\mathrm{H}$, Liakou $\mathrm{Cl}$, Kamat $\mathrm{A}$, et al.: Anti-CTLA-4 therapy results in higher $\mathrm{CD}^{+}{ }^{+} \mathrm{ICOS}^{\mathrm{hi}} \mathrm{T}$ cell frequency and IFN-gamma levels in both nonmalignant and malignant prostate tissues. Proc Natl Acad Sci U S A. 2009; 106(8): 2729-34. PubMed Abstract | Publisher Full Text | Free Full Text

43. $\mathrm{F}$ Liakou $\mathrm{Cl}$, Kamat $\mathrm{A}$, Tang DN, et al:: CTLA-4 blockade increases IFNgammaproducing $C D 4^{+}{ }^{+} \mathrm{COS}^{\mathrm{hi}}$ cells to shift the ratio of effector to regulatory $\mathrm{T}$ cells in cancer patients. Proc Natl Acad Sci U S A. 2008; 105(39): 14987-92. PubMed Abstract | Publisher Full Text | Free Full Text | F1000 Recommendation

44. Harlin $\mathrm{H}$, Meng $\mathrm{Y}$, Peterson AC, et al:: Chemokine expression in melanoma metastases associated with CD8 ${ }^{+}$T-cell recruitment. Cancer Res. 2009; 69(7): 3077-85.

PubMed Abstract | Publisher Full Text | Free Full Text

45. F Mikucki ME, Fisher DT, Matsuzaki J, et al:: Non-redundant requirement for CXCR3 signalling during tumoricidal T-cell trafficking across tumour vascular checkpoints. Nat Commun. 2015; 6(7458): 7458.

PubMed Abstract | Publisher Full Text | Free Full Text | F1000 Recommendation

46. Fuertes MB, Woo SR, Burnett B, et al:: Type I interferon response and innate immune sensing of cancer. Trends Immunol. 2013; 34(2): 67-73.

PubMed Abstract | Publisher Full Text | Free Full Text

47. Pestka S, Krause CD, Walter MR: Interferons, interferon-like cytokines, and their receptors. Immunol Rev. 2004; 202(1): 8-32. PubMed Abstract | Publisher Full Text

48. F Chiappinelli KB, Strissel PL, Desrichard A, et al:: Inhibiting DNA Methylation Causes an Interferon Response in Cancer via dsRNA Including Endogenous Retroviruses. Cell. 2015; 162(5): 974-86.

PubMed Abstract | Publisher Full Text | Free Full Text | F1000 Recommendation

49. Spranger S, Spaapen RM, Zha Y, et al.: Up-regulation of PD-L1, IDO and Tregs $_{\text {in }}$ the melanoma tumor microenvironment is driven by $\mathrm{CD8}^{+} \mathrm{T}$ cells. Sci Trans/ Med. 2013; 5(200): 200ra116.

PubMed Abstract | Publisher Full Text | Free Full Text

50. Taube JM, Anders RA, Young GD, et al:: Colocalization of inflammatory response with B7-h1 expression in human melanocytic lesions supports an adaptive resistance mechanism of immune escape. Sci Transl Med. 2012; 4(127): 127ra37.

PubMled Abstract | Publisher Full Text | Free Full Text

51. F Schmidt LH, Kümmel A, Görlich D, et al.: PD-1 and PD-L1 Expression in NSCLC Indicate a Favorable Prognosis in Defined Subgroups. PLoS One. 2015; 10(8): e0136023.

PubMed Abstract | Publisher Full Text | Free Full Text | F1000 Recommendation

52. F Schalper KA, Velcheti V, Carvajal D, et al.: In situ tumor PD-L1 mRNA expression is associated with increased TILs and better outcome in breast carcinomas. Clin Cancer Res. 2014; 20(10): 2773-82.

PubMed Abstract | Publisher Full Text | F1000 Recommendation

53. F Ott PA, Hodi FS, Robert C: CTLA-4 and PD-1/PD-L1 blockade: new immunotherapeutic modalities with durable clinical benefit in melanoma patients. Clin Cancer Res. 2013; 19(19): 5300-9.

PubMed Abstract | Publisher Full Text | F1000 Recommendation

54. F Topalian SL, Hodi FS, Brahmer JR, et al:: Safety, activity, and immune correlates of anti-PD-1 antibody in cancer. N Engl J Med. 2012; 366(26): 2443-54. PubMed Abstract | Publisher Full Text | Free Full Text | F1000 Recommendation

55. F Parsa AT, Waldron JS, Panner A, et al.: Loss of tumor suppressor PTEN function increases B7-H1 expression and immunoresistance in glioma. Nat Med. 2007; 13(1): 84-8.

PubMed Abstract | Publisher Full Text | F1000 Recommendation

56. $\mathrm{F}$ Madore J, Vilain RE, Menzies AM, et al.: PD-L1 expression in melanoma shows marked heterogeneity within and between patients: implications for anti-PD-1/PD-L1 clinical trials. Pigment Cell Melanoma Res. 2015; 28(3): 245-53. PubMed Abstract | Publisher Full Text | F1000 Recommendation

57. F Highfill SL, Cui Y, Giles AJ, et al.: Disruption of CXCR2-mediated MDSC tumor trafficking enhances anti-PD1 efficacy. Sci Transl Med. 2014; 6(237): 237 ra67.

PubMed Abstract | Publisher Full Text | F1000 Recommendation

58. F Peggs KS, Quezada SA, Chambers CA, et al: Blockade of CTLA-4 on both effector and regulatory $\mathrm{T}$ cell compartments contributes to the antitumor activity of anti-CTLA-4 antibodies. J Exp Med. 2009; 206(8): 1717-25. PubMed Abstract | Publisher Full Text | Free Full Text | F1000 Recommendation

59. F Simpson TR, Li F, Montalvo-Ortiz W, et al.: Fc-dependent depletion of tumorinfiltrating regulatory T cells co-defines the efficacy of anti-CTLA-4 therapy against melanoma. J Exp Med. 2013; 210(9): 1695-710.

PubMed Abstract | Publisher Full Text | Free Full Text | F1000 Recommendation

60. Hooper LV, Littman DR, Macpherson AJ: Interactions between the microbiota and the immune system. Science. 2012; 336(6086): 1268-73. PubMed Abstract | Publisher Full Text | Free Full Text

61. F Abt MC, Osborne LC, Monticelli LA, et al.: Commensal bacteria calibrate the activation threshold of innate antiviral immunity. Immunity. 2012; 37(1): 158-70. PubMed Abstract | Publisher Full Text | Free Full Text | F1000 Recommendation

62. F Sivan A, Corrales L, Hubert N, et al.: Commensal Bifidobacterium promotes antitumor immunity and facilitates anti-PD-L1 efficacy. Science. 2015; 350(6264): 1084-9.

PubMed Abstract | Publisher Full Text | Free Full Text | F1000 Recommendation

63. Xue W, Zender L, Miething $\mathrm{C}$, et al:: Senescence and tumour clearance is triggered by p53 restoration in murine liver carcinomas. Nature. 2007; 445(7128): 656-60.

PubMed Abstract | Publisher Full Text | Free Full Text

64. Iannello A, Thompson TW, Ardolino M, et al:: p53-dependent chemokine production by senescent tumor cells supports NKG2D-dependent tumor elimination by natural killer cells. J Exp Med. 2013; 210(10): 2057-69. PubMed Abstract | Publisher Full Text | Free Full Text

65. F Madore J, Strbenac D, Vilain R, et al:: PD-L1 Negative Status is Associated with Lower Mutation Burden, Differential Expression of Immune-Related Genes, and Worse Survival in Stage III Melanoma. Clin Cancer Res. 2016; 22(15): 3915-23.

PubMed Abstract | Publisher Full Text | F1000 Recommendation

66. F Shin D, Garcia-Diaz A, Zaretsky J, et al.: Innate resistance of PD-1 blockade through loss of function mutations in JAK resulting in inability to express PD-L1 upon interferon exposure. J Immunother Cancer. 2015; 3(Suppl 2): P311. Publisher Full Text | Free Full Text | F1000 Recommendation

67. F Ikeda S, Okamoto T, Okano S, et al.: PD-L1 Is Upregulated by Simultaneous Amplification of the PD-L1 and JAK2 Genes in Non-Small Cell Lung Cancer. J Thorac Oncol. 2016; 11(1): 62-71.

PubMed Abstract | Publisher Full Text | F1000 Recommendation

68. F Peng W, Chen JQ, Liu C, et al.: Loss of PTEN Promotes Resistance to T Cell-Mediated Immunotherapy. Cancer Discov. 2016; 6(2): 202-16. PubMed Abstract | Publisher Full Text | Free Full Text | F1000 Recommendation

69. Marzec M, Zhang Q, Goradia A, et al:: Oncogenic kinase NPM/ALK induces through STAT3 expression of immunosuppressive protein CD274 (PD-L1, B7H1). Proc Natl Acad Sci U S A. 2008; 105(52): 20852-7. PubMed Abstract | Publisher Full Text | Free Full Text

70. Garon EB, Rizvi NA, Hui R, et al: Pembrolizumab for the treatment of non-smallcell lung cancer. N Engl J Med. 2015; 372(21): 2018-28. PubMed Abstract | Publisher Full Text

71. F Spranger S, Bao R, Gajewski TF: Melanoma-intrinsic $\beta$-catenin signalling prevents anti-tumour immunity. Nature. 2015; 523(7559): 231-5. PubMed Abstract | Publisher Full Text | F1000 Recommendation

72. F Fuertes MB, Kacha AK, Kline J, et al.: Host type I IFN signals are required for antitumor $\mathrm{CD}^{+} \mathrm{T}$ cell responses through $\mathrm{CD} 8\{$ alpha\}+ dendritic cells. J Exp Med. 2011; 208(10): 2005-16.

PubMed Abstract | Publisher Full Text | Free Full Text | F1000 Recommendation

73. F Van Lint S, Renmans D, Broos K, et al.: Intratumoral Delivery of TriMix mRNA Results in T-cell Activation by Cross-Presenting Dendritic Cells. Cancer Immunol Res. 2016; 4(2): 146-56.

PubMed Abstract | Publisher Full Text | F1000 Recommendation

74. F Fu J, Kanne DB, Leong M, et al.: STING agonist formulated cancer vaccines can cure established tumors resistant to PD-1 blockade. Sci Trans/ Med. 2015; 7(283): 283ra52.

PubMed Abstract | Publisher Full Text | Free Full Text | F1000 Recommendation

75. F Blank CU, Haanen JB, Ribas A, et al:: CANCER IMMUNOLOGY. The "cancer immunogram". Science. 2016; 352(6286): 658-60.

PubMed Abstract | Publisher Full Text | F1000 Recommendation 


\section{Open Peer Review}

\section{Current Peer Review Status:}

\section{Editorial Note on the Review Process}

Faculty Reviews are review articles written by the prestigious Members of Faculty Opinions. The articles are commissioned and peer reviewed before publication to ensure that the final, published version is comprehensive and accessible. The reviewers who approved the final version are listed with their names and affiliations.

\section{The reviewers who approved this article are:}

\section{Version 1}

\section{Daniel Speiser}

Department of Oncology, Ludwig Center for Cancer Research, University of Lausanne, Epalinges, Switzerland

Competing Interests: No competing interests were disclosed.

\section{Timothy M Illidge}

Division of Molecular and Clinical Cancer Sciences, Faculty of Biology, Medicine and Health, The University of Manchester, Manchester, UK

Competing Interests: No competing interests were disclosed.

\section{Karine Breckpot}

Laboratory of Molecular and Cellular Therapy, Department of Biomedical Sciences, Vrije Universiteit Brussel, Brussels, Belgium

Competing Interests: No competing interests were disclosed.

The benefits of publishing with F1000Research:

- Your article is published within days, with no editorial bias

- You can publish traditional articles, null/negative results, case reports, data notes and more

- The peer review process is transparent and collaborative

- Your article is indexed in PubMed after passing peer review

- Dedicated customer support at every stage

For pre-submission enquiries, contact research@f1000.com 